\title{
Organising the Training Process in Polish Companies Operating on International Markets
}

\begin{abstract}
Training programmes enable employees to develop general and firm-specific competences. In companies that operate on international markets, such programmes also provide the transfer of best practices, routines and procedures between the parent firm and subsidiary. Given the importance of human capital in building sustainable competitive advantage, the training process should be professionally designed and executed. Operating on the domestic market makes it easier to properly design and execute training than it is for companies entering foreign markets. The article presents the results of research that sought to verify the professionalisation of training in 50 Polish companies entering foreign markets. General guidelines for how the process should be executed and the People Capability Maturity Model were used to evaluate the training.
\end{abstract}

Keywords: training, multinational enterprises, organisational capabilities, human capital, organisational growth.

JEL Classification: M160, M53, M54.

\section{Introduction}

The paper presents the results of research conducted to determine how Polish companies that operate on international markets organise training and how this process may affect the development of employee competencies. The majority of

Urban Pauli, Cracow University of Economics, Department of Human Capital Management, Rakowicka 27, 31-510 Kraków, Poland, e-mail: urban.pauli@uek.krakow.pl 
companies enter foreign markets once they are mature and have implemented well-designed internal processes. These processes are based on routines and use organisational capabilities to enhance performance. One of these processes is training, which not only enables employees to develop competences but also ensures the transfer of procedures, best-practices and tacit knowledge. Operating entirely on one (domestic) market reduces the challenges involved when multiple markets are in play. In the latter case, companies must decide to what extent they should implement training procedures in subsidiaries or to adopt procedures specific to the local market. This dilemma may cause variation in the way training is organised and particular differences may render knowledge transfer and competency development less effective.

This article is divided into three parts. The first discusses theories of organisational growth, in order to have an overview of the maturity of internal processes of organisations entering international markets. On the basis of these theories, the commonly implemented level of internal process formalisation will be presented. This will be followed up by an analysis of the importance of human capital for companies entering new markets and the role of training in transferring knowledge and best practices. The second section contains the results of research on training process maturity in Polish companies operating on international markets. Maturity means that the processes are designed in accordance with knowledge and best practices, and they are capable of delivering high performance over time (Hammer 2007, p. 113). That is followed by a discussion and evaluation of training process maturity in the companies investigated.

\section{Organisational Growth and Internationalisation}

Expansion on foreign markets is a process undertaken predominantly by mature companies. Their development makes it possible and often necessary to enter new markets because (1) companies have a surplus in productivity potential; (2) have a unique product or service seen to have sales potential on foreign markets; or (3) operating on foreign markets is the best way to survive tightening domestic markets (as a result of competitors' increasing activity, for example). Theories of organisational growth indicate the stage at which companies are more likely to enter foreign markets (Table 1).

Organisational growth theories suggest the following three major points about companies starting to expand on foreign markets: (1) they have well-developed know-how, best-practices and routines and are capable of achieving high performance; (2) internal processes are well-developed and internal procedures are highly formalised (including HRM practices); (3) they have a well-established 
position on their domestic market, which means having a well-known product/ service and appropriate income from it.

Table 1. The Requirements for Resources on Growth Stages

\begin{tabular}{|c|c|c|c|}
\hline Authors & $\begin{array}{c}\text { Stages of growth } \\
\text { presented in models }\end{array}$ & \begin{tabular}{|c|}
$\begin{array}{c}\text { Stages in which } \\
\text { internalisation } \\
\text { may appear }\end{array}$ \\
\end{tabular} & Characteristics \\
\hline $\begin{array}{l}\text { Churchil and } \\
\text { Lewis (1983) }\end{array}$ & $\begin{array}{l}\text { - existence } \\
\text { - survival } \\
\text { - success } \\
\text { - take-off } \\
\text { - maturity }\end{array}$ & success-growth & $\begin{array}{l}\text { Internationalisation may be the next } \\
\text { stage of development when entrepre- } \\
\text { neurs choose the path of success-growth } \\
\text { followed by take-off. In these stages } \\
\text { companies focus on gaining financing } \\
\text { and shaping internal procedures and } \\
\text { structures }\end{array}$ \\
\hline $\begin{array}{l}\text { Quinn and } \\
\text { Cameron } \\
(1983)\end{array}$ & $\begin{array}{l}\text { - entrepreneurial } \\
\text { - collectivity } \\
\text { - formalisation and } \\
\text { control } \\
\text { - elaboration of } \\
\text { structures }\end{array}$ & $\begin{array}{l}\text { formalisation } \\
\text { and control }\end{array}$ & $\begin{array}{l}\text { Formalisation of rules and institution- } \\
\text { alisation of procedures appear in the } \\
\text { formalisation and control stage. However, } \\
\text { actions connected with expansion can be } \\
\text { introduced both in formalisation and con- } \\
\text { trol as well as in elaboration of structures }\end{array}$ \\
\hline $\begin{array}{l}\text { Scott and } \\
\text { Bruce (1987) }\end{array}$ & $\begin{array}{l}\text { - inception } \\
\text { - survival } \\
\text { - growth } \\
\text { - expansion } \\
\text { - maturity }\end{array}$ & expansion & $\begin{array}{l}\text { There are many procedures introduced, } \\
\text { decentralised authority and systemised } \\
\text { administrative functions. In the growth } \\
\text { stage, companies develop new products } \\
\text { and search for new markets that play } \\
\text { a crucial role for further growth and } \\
\text { expansion }\end{array}$ \\
\hline $\begin{array}{l}\text { Hanks et al. } \\
(1993)\end{array}$ & $\begin{array}{l}\text { - start-up } \\
\text { - expansion } \\
\text { - maturity } \\
\text { - diversification }\end{array}$ & maturity & $\begin{array}{l}\text { Organisational structures are complex, } \\
\text { the level of formalisation is increasing. } \\
\text { In such companies there are in general } \\
\text { more than } 10 \text { specialised functions }\end{array}$ \\
\hline Greiner (1998) & $\begin{array}{l}\text { - creativity } \\
\text { - direction } \\
\text { - delegation } \\
\text { - coordination } \\
\text { - collaboration }\end{array}$ & coordination & $\begin{array}{l}\text { Activities connected with formalisation } \\
\text { and shaping procedures appear in organi- } \\
\text { sations in the fourth stage of develop- } \\
\text { ment, called coordination. In this stage, } \\
\text { new systems arise and companies may } \\
\text { intensify their international activity }\end{array}$ \\
\hline Adizes (2004) & $\begin{array}{l}\text { - courtship } \\
\text { - infacy } \\
\text { - go-go } \\
\text { - adolescence } \\
\text { - prime } \\
\text { - the signs of aging } \\
\text { - aristocracy } \\
\text { - early bureucracy } \\
\text { - bureucracy } \\
\text { - death }\end{array}$ & prime & $\begin{array}{l}\text { In the prime stage, internal procedures } \\
\text { and routines are established and organisa- } \\
\text { tions can easily structure their priorities. } \\
\text { In this stage as well as in the signs of } \\
\text { aging, companies are able to act outside } \\
\text { domestic markets }\end{array}$ \\
\hline
\end{tabular}


Table 1 cnt'd

\begin{tabular}{|c|l|c|c|}
\hline \multicolumn{1}{|c|}{ Authors } & $\begin{array}{c}\text { Stages of growth } \\
\text { presented in models }\end{array}$ & $\begin{array}{c}\text { Stages in which } \\
\text { internalisation } \\
\text { may appear }\end{array}$ & \multicolumn{1}{c|}{ Characteristics } \\
\hline $\begin{array}{l}\text { Flamholtz and } \\
\text { Randle (2007) }\end{array}$ & $\begin{array}{l}\text { - new venture } \\
\text { - expansion } \\
\text { - professionalisa- } \\
\text { tion } \\
\text { - consolidation } \\
\text { - diversification } \\
\text { - integration } \\
\text { - decline }\end{array}$ & diversification & $\begin{array}{l}\text { The critical development area of organi- } \\
\text { sations in the fifth stage of development } \\
\text { (diversification) is entering new markets } \\
\text { and developing or inventing new prod- } \\
\text { ucts. These activities are preceded by } \\
\text { consolidation and, more importantly, } \\
\text { the professionalisation of resources and } \\
\text { operational systems }\end{array}$ \\
\hline
\end{tabular}

Source: (Churchil \& Lewis 1983, Quinn \& Cameron 1983, Scott \& Bruce 1987, Hanks et al. 1993 , Greiner 1998, Adizes 2004, Flamholtz \& Randle 2007).

\section{The Importance of Human Capital in Entering New Markets}

According to growth models, organisations that are able to enter foreign markets:

- have a well-established market position,

- have a well-known brand and product/service on local markets,

- possess a surplus of craft potential (in order to produce/offer amounts of products/services depending on the new level of demand they encounter in the new markets),

- have growing incomes and financial capital ready to invest.

Although these characteristics can help build competitive advantage, they remain somewhat insufficient. Human capital is the factor most commonly reported to have the highest impact on firms' performance and success. Such a view takes into account the importance of intangible assets in building sustainable competitive advantage. According to Barney (1991), companies may use their resources, including physical capital, human capital and organisational capital, to implement their strategies, but only those with VRIN attributes (valuable, rare, inimitable, non-substitutable) create real advantage (Barney 1991). Relying on the resource-based view of the firm (RBV), Galbreath (2005) sought to identify which resources are most important for companies. He hypothesised that intellectual property assets, organisational assets and reputational assets contribute more significantly to the firm's success than do tangible assets. Moreover, organisational capabilities (including skills and knowledge, both components of human capital) have the greatest impact on the firm's success (Galbreath 2005, pp. 981-82). These hypotheses were borne out by the research. Similarly, Pike, 
Roos and Marr (2005) used case studies to prove the importance of intangible assets, including human capital, in the value creation process.

Human capital is a major factor in creating a company's competitive advantage (Schultz 1961). Precisely identifying its components, let alone putting them together, is difficult, and may make the replication of human capital impossible (Shaw, Park \& Kim 2013). The more firm-specific the components of human capital are, the more difficult it is to imitate them and the more valuable they are for companies (Hatch \& Dyer 2004). Such an effect can be observed even if some knowledge can be replicated, because human capital is a source of continuing knowledge creation and enables the firm to build or improve its capabilities.

\section{The Role of Training in Building Success on International Markets}

Theories of growth posit that internationalisation is preceded by the shaping and formalising of internal processes, which positively affects performance. According to Hammer (2007), organisations can perform well if they have welldesigned processes, because employees possess a set of specifications describing how they are to perform, as well as where, with which tools and under what circumstances. According to Hammer's model, these characteristics come into play in the third level of process maturity, when "a process delivers optimal performance because executives can integrate it with other internal processes to maximize its contribution to the company's performance" (Hammer 2007, p. 114). Achieving this level requires not only accurately designed processes, but also the appropriate infrastructure and HR systems to be in place (Hammer 2007). Without well-designed HR systems, it would be impossible to teach people how to perform, provide them with competences, and evaluate and reward their outputs. This means that HR systems should be designed on the basis of mature processes themselves.

The HR system should seek to create conditions that stimulate the acquisition and implementation of new knowledge as well as the transformation of existing knowledge into new models of acting (Pocztowski 2003). These processes directly correspond with Lepak and Snell's (1999) HR architecture model, which describes the ways in which companies can increase the value of human capital. Although all these processes may appear in companies operating on international markets, acquisition and internal development seem to be the most adequate when starting new ventures. Acquisition refers to recruitment and selection, and allows organisations to employ a workforce with job-related knowledge, skills and abilities (KSA). Internal development refers mostly to training intended to 
enhance KSAs, and develop those that are firm-specific (Kwon \& Rupp 2013). Both processes enable organisational learning, which is crucial if competitive advantage is to be gained on foreign markets. Similarly, according to Simon (1991), organisational learning can be reached in two ways: by employing those who possess knowledge the firm has lacked (acquisition) or by having employees learn (internal development process). While an organisation may indeed have developed valuable human capital by both means, training is the superior route as it enables the firm to create or improve firm-specific competences.

Training is the process by which a company can upgrade the knowledge, skills and abilities employees need to perform their jobs and accelerate the flow of codified and tacit knowledge (Curtis, Hefley \& Miller 2009, Moumita \& Zaman 2013). The significance of human capital as a source of sustainable competitive advantage makes it necessary to redefine and widen the scope of and intensify training in companies operating on international markets (Pauli 2015, p. 151). The main goals include the following: (1) provide development of crucial KSAs by creating an opportunity to learn, which will result in higher performance. Training should (2) teach how to run processes within the whole organisation, as knowledge, especially the tacit variety, can be revealed only by actually being applied (Grant 1996). Training policies (3) create an internal environment that enhances the company's ability to learn, which is a crucial factor in innovations coming into being. Introducing new knowledge and developing and distributing existing knowledge develops a new way of perceiving or understanding things, which may play an important role when coming to grips with the environmental changes that accompany a company's entrance to new markets (Chiva, Ghauri \& Alegre 2013). Well-designed training also (4) boosts productivity, mostly because individual specialised skills are emphasised or enhanced (Valle et al. 2000). (5) Training strengthens the psychological contract between the employee and the company. Those who receive training, especially when it covers general competences (Becker 1962), regard it as a gift and treated it as a sign of commitment on the part of the employer. This will result in decreased employee turnover (Barrett \& O'Connell 2001, Kwon \& Rupp 2013).

Additionally, training plays a crucial role in (6) spreading the organisation's routines, which originate from abilities developed in the parent company. Such routines have a tacit component and are very often treated as best practices. They apply to the way organisations use their knowledge (Szulanski 1996). High velocity markets often multiply the information and opportunities that come about, but these in turn generate significant uncertainty (Eisenhardt \& Martin 2000). To help employees focus on accomplishing their goals, internal routines must be followed and can be taught by training. To this end, global training programmes can be implemented into every branch of a multinational 
company (Moumita \& Zaman 2013). Additionally internationalisation is viewed as a learning and knowledge accumulating process, which leads firms operating on international markets to generate more knowledge than their counterparts that confine themselves to national market (Chiva, Ghauri \& Alegre 2013). This learning opportunity can be attributed to ideas coming from a greater number of new and different markets and cultural perspectives (Pittiglio, Sica \& Villa 2013). New knowledge gained from everyday experience can be (7) captured and structured during trainings, especially ones that provide interaction and the open flow of information among participants.

\section{Evaluating the Maturity of Training Offered by Polish Companies}

This section examines training processes in Polish MNEs operating on international markets. It is assumed that maturity in the training process is essential for taking actions aimed at creating and organising the transfer of knowledge in subsidiaries. The People Capability Maturity Model (Curtis, Hefley \& Miller 2009) can be used to shape training programmes. According to the model, organisations should: (1) establish and maintain a documented policy for conducting training activities, (2) identify training needs in critical competences, (3) develop and maintain training plans in accordance with the needs of individuals and units, (4) provide training that uses the most effective techniques for developing required knowledge and skills, (5) verify the effects of training (Curtis, Hefley $\&$ Miller 2009). To evaluate the training process, maturity, needs analysis procedures, and methods of planning, conducting and evaluating training programmes should be taken into account.

The research on training policies in MNEs was conducted in the years 20132015 as a part of a project entitled "HRM practices in companies intensifying international business", carried out by the Department of Human Capital Management of Cracow University of Economics. For its research sample, the project looked at Polish companies operating on foreign markets or which were planning to do so. According to the establishment chain (Johanson \& Vahlne 1990), which consisted of four stages, we were interested in companies that belonged to a third one - in other words, those operating on foreign markets via a subsidiary. Market research identified 143 companies as potential respondents, which were invited to take part in the research. 50 enterprises eventually agreed to participate in the project. All were Polish-owned enterprises, and most of them had more than 10 years' experience operating on international markets. Table 2 breaks down the characteristics of the final sample. 
Table 2. Sample Characteristics (Percent of the Sample)

\begin{tabular}{|c|c|c|c|c|c|c|}
\hline \multicolumn{4}{|c|}{ Criterion } \\
\hline \multicolumn{3}{|c|}{ Company size } & \multicolumn{4}{c|}{ Years on international markets } \\
\hline small & medium & large & up to 2 & $2-5$ years & $6-10$ years & $\begin{array}{c}11 \text { years } \\
\text { and above }\end{array}$ \\
\hline 4 & 20 & 76 & 2 & 4 & 16 & 78 \\
\hline
\end{tabular}

Source: the author's own elaboration.

The data were collected with PAPI, using a questionnaire consisting of 63 questions covering major issues of HRM practices in both the parent company and the subsidiary as well as the relations between them. Seven of the questions concerned training practices and covered issues connected with training: needs evaluation, planning, methods used, ways of evaluating competency development programmes, and the level of formalisation in the training procedures.

\section{Results}

The majority of companies (90\%) confirmed they designed a human resource management strategy, but only $58 \%$ recorded it as an internal document. Nevertheless, $82 \%$ claimed to have formalised and written training procedures. This accords with Nikandrou, Apospori and Papalexandris' conclusion that training suggests a systematic rather than an ad hoc approach (2008, p. 327).

Most of the companies plan their training activities for a greater than oneyear perspective $(60 \%)$. However, a good number fail to plan training activities, choosing instead to merely react to emerging needs $(22 \%)$; others set plans for only a half-year perspective (18\%). Such an attitude can take a toll on strategy execution and make it difficult to reach the appropriate level of performance.

Analysis of the particular stages of the training process shows that they are done without unified praxis. The assessment of training needs revealed that the techniques used can be insufficient and poor. The most common techniques include examining the level of performance $(66 \%)$ and conducting an individual interview with the person to be trained (64\%). As few as a third of the companies use the results of appraisals to create development plans (see Table 3). Comparison of these data with Cranet's results shows that employees' suggestions are taken into account less frequently in Polish companies than in their counterparts elsewhere in the EU (Nikandrou, Apospori \& Papalexandris 2008, p. 327).

The most commonly used training techniques involve routines, standards and executive practices. $82 \%$ of companies use specialised guided instructions, $76 \%$ apply simulations with role-play activities, and $64 \%$ use practical on-the-job 
training. $72 \%$ declare that they provide postgraduate studies for their employees. Nearly four in ten companies offer e-learning programmes that directly refer to organisational routines and develop crucial competencies (see Table 4).

Table 3. Methods of Assessing Training Needs

\begin{tabular}{|l|c|}
\hline \multicolumn{1}{|c|}{ Method } & Percent of the sample \\
\hline Performance appraisal & 66 \\
\hline Direct interview with the employee & 64 \\
\hline Suggestions of supervisor & 48 \\
\hline On-the-job observation & 36 \\
\hline Results of customer satisfaction surveys & 32 \\
\hline Result of appraisal systems & 30 \\
\hline Third-party suggestions & 22 \\
\hline Individual employee suggestions & 16 \\
\hline Analysis of personnel documents & 12 \\
\hline Results of surveys conducted among employees & 8 \\
\hline
\end{tabular}

Source: the author's own elaboration.

Table 4. The Training Techniques Used

\begin{tabular}{|l|c|}
\hline \multicolumn{1}{|c|}{ Techniques } & Percent of the sample \\
\hline Specialised guided instructions & 82 \\
\hline Simulations (role play) & 76 \\
\hline Post graduate studies & 72 \\
\hline Practical on-the-job training & 64 \\
\hline Presentations & 62 \\
\hline Job rotation among subsidiaries & 46 \\
\hline Lectures & 46 \\
\hline Case studies & 42 \\
\hline Group work & 42 \\
\hline Coaching & 38 \\
\hline E-learning & 36 \\
\hline Mentoring & 34 \\
\hline Job rotation between subsidiary and parent organisation & 32 \\
\hline Blended learning & 2 \\
\hline
\end{tabular}

Source: the author's own elaboration.

The last stage of the training process (Pocztowski 2007) is training evaluation, which all of the companies indicated they did. The most common techniques are interviews with participants during or after the training and a knowledge test. 
These techniques correspond to the first and second level of Kirkpatrick's (2007) model. A third of companies evaluate performance achieved after the training and compare it with results of the test conducted prior to the training (see Table 5).

Table 5. Techniques Used to Evaluate Training

\begin{tabular}{|l|c|}
\hline \multicolumn{1}{|c|}{ Techniques } & Percent of the sample \\
\hline Interviews with participants during or after training & 58 \\
\hline Testing knowledge before and after training & 54 \\
\hline Post-training satisfaction surveys & 42 \\
\hline Verifying the application of new knowledge and skills on the post & 40 \\
\hline Evaluating knowledge after training during an interview & 38 \\
\hline Evaluation of performance after and before training & 36 \\
\hline Tests verifying skills after training & 28 \\
\hline Test verifying knowledge after training & 26 \\
\hline Co-workers opinion about changes in acting on the post & 18 \\
\hline We use appraisal system to verify changes & 18 \\
\hline Verifying customer opinions & 12 \\
\hline We do not carry out evaluations & 0 \\
\hline
\end{tabular}

Source: the author's own elaboration.

The results show that the vast majority of companies (90\%) have designed a human resource management strategy, and in most cases formalised it as an internal document. Eight in ten companies claim they have introduced written procedures for their training programmes.

\section{Discussion}

My analysis of three crucial stages of the training process (needs assessment, planning and evaluation) leads to the conclusion that the level of professionalisation varies by company. To gain a complex view of the situation, different sources of information should be used to assess the training needs. These sources can be divided into four groups: (1) performance level, (2) employee/participant expectations, (3) supervisor requirements and (4) third-party opinion (co-workers, internal customers, customers) (Bee \& Bee 1994, Boydell \& Leary 1996). It is preferable that the process should use such sources that enable information to be gathered from all four perspectives. Unfortunately, that occurs in only $30 \%$ of companies, while $42 \%$ use sources limited to only one perspective.

Nine in ten of the companies investigated employed techniques that provide skills and knowledge improvement. 26\% conduct training evaluations on all four 
levels of Kirkpatrick's model while another $40 \%$ apply techniques that enable evaluations to be made on three levels. $56 \%$ of the organisations from these two groups evaluate the impact of training on performance. The majority of companies $(74 \%)$ describe their training practices as cyclical, containing all stages of the training process while $60 \%$ prepare a development plan for a one-year or longer perspective. This proves that the majority of companies execute training in a professional or semi-professional manner, and that some improvements, especially in needs assessment, should occur.

Table 6. Comparison of Training Process Practice in MNEs and PCMM Guidelines

\begin{tabular}{|l|l|}
\hline \multicolumn{1}{|c|}{ Model guidelines } & \multicolumn{1}{|c|}{ Description of practices in investigated MNE } \\
\hline $\begin{array}{l}\text { Organisation establishes and maintains } \\
\text { a documented policy for conducting train- } \\
\text { ing activities }\end{array}$ & $\begin{array}{l}\text { Only } 58 \% \text { confirmed to have a written HRM strat- } \\
\text { egy. This means the number with a T\&D strategy } \\
\text { may be lower }\end{array}$ \\
\hline $\begin{array}{l}\text { Training needed in critical skills is identi- } \\
\text { fied for each individual }\end{array}$ & $\begin{array}{l}\text { Only } 64 \% \text { of respondents claim they conduct } \\
\text { a direct interview with employees to identify train- } \\
\text { ing needs. Only in } 16 \% \text { of companies are employ- } \\
\text { ees' suggestions taken into account }\end{array}$ \\
\hline $\begin{array}{l}\text { Each unit develops and maintains a plan } \\
\text { for satisfying its training needs }\end{array}$ & $\begin{array}{l}22 \% \text { of companies do not plan their training activi- } \\
\text { ties and an additional } 18 \% \text { set plans for a six-month } \\
\text { timeline. This approach seems to react to emerging } \\
\text { needs rather than to involve plans for satisfying } \\
\text { training needs }\end{array}$ \\
\hline $\begin{array}{l}\text { A development discussion is held periodi- } \\
\text { cally with each individual }\end{array}$ & $\begin{array}{l}\text { In only } 64 \% \text { of companies are employees inter- } \\
\text { viewed directly to identify training needs. In only } \\
38 \% \text { is knowledge gained during training evalu- } \\
\text { ated during individual interviews }\end{array}$ \\
\hline $\begin{array}{l}\text { Relevant development opportunities are } \\
\text { made available to support individuals in } \\
\text { accomplishing their development objec- } \\
\text { tives }\end{array}$ & $\begin{array}{l}\text { In only 38\% of companies are coaching pro- } \\
\text { grammes available for employees. 34\% of } \\
\text { companies provide employees with mentoring } \\
\text { programmes. This means that in many organisa- } \\
\text { tions individual forms of developing competences } \\
\text { were not implemented }\end{array}$ \\
\hline
\end{tabular}

Source: the author, based on (Curtis, Hefley \& Miller 2009, pp. 169-79).

My research further confirms that companies employ reverse transfer, a process described by Liu (2004). In 30\% of cases an expatriate returning from the visiting country is obligated to share his knowledge with other employees by conducting workshops, preparing documents or giving presentations. $46 \%$ of companies transfer employees between subsidiaries, and $32 \%$ have the parent company host employees from the subsidiary. These practices surely facilitate the reverse transfer of knowledge and organisational learning. 
Comparison of the data gathered with the People Capability Maturity Model reveals a number of discrepancies between the way the Polish MNEs perform training and the guidelines included in the model. First, few Polish MNEs offer fully-professional training, which is to say training that accords with the PCMM. Although most prepare an overall strategy and goals for HRM, the training subprocesses are flawed. Needs assessment fails to cover all of the required issues, which leaves the development of crucial competences unachieved. Training methods fall short in providing the desired increase in knowledge, skills and employee attitudes. Moreover, MNEs conduct imprecise evaluations and often fail to verify the impact on performance. Table 6 presents particular examples of discrepancies between the training process in the MNEs investigated and directions stated for the third level of training process maturity (according to PCMM).

All of these oversights and mistakes may create obstacles to building competitive advantage while operating on foreign markets. The possibility to use knowledge, routines, procedures and best practices developed in the parent organisation will be limited due to the low level of professionalisation in training. Such difficulties can be additionally impacted by environmental factors, which may especially affect Polish MNEs accustomed to operating in a homogeneous market.

\section{Limitations and Proposals for Further Study}

There are several limitations concerning the theses and analyses this paper has presented. The most important one is that, at only 50, the small number of companies investigated makes it impossible to generalise the entire population. Thus it is necessary to conduct in-depth analyses that cover a larger sample. The maturity of the training process should be evaluated and then how companies organise and audit this process in subsidiaries must be verified. The results should be correlated with overall performance indicators as well as with the extent to which the goals of the training are achieved. This will make it possible to determine which of the training's subprocesses have the highest impact on knowledge transfer and performance in firms that expand their international business operations.

\section{Bibliography}

Adizes I. (2004), Managing Corporate Lifecycles, Adizes Institute Publications, Carpinteria. Barney J.B. (1991), Firm Resources and Sustained Competitive Advantage, "Journal of Management", vol. 17, no 1, https://doi.org/10.1177/014920639101700108.

Barrett A., O’Connell P.J. (2001), Does Training Generally Work? The Returns to in Company Training, "Industrial and Labor Relations Review", vol. 54, no 3, https://doi. org/10.1177/001979390105400307. 
Becker G.S. (1962), Investment in Human Capital: A Theoretical Analysis, "The Journal of Political Economy", vol. 70, no 5, https://doi.org/10.1086/258724.

Bee F., Bee R. (1994), Training Needs Analysis and Evaluation, Institute of Personnel Management, London.

Boydell T., Leary M. (1996), Identifying Training Needs, Chartered Institute of Personnel Development, London.

Chiva R., Ghauri P., Alegre J. (2013), Organizational Learning, Innovation and Internationalization: A Complex System Model, "British Journal of Management", vol. 25, no 4, https://doi.org/10.1111/1467-8551.12026.

Churchil N.C., Lewis V.L. (1983), The Five Stages of Small Business Growth, "Harvard Business Review", vol. 61, no 3.

Curtis B., Hefley B., Miller S. (2009), People Capability Maturity Model Version 2.0, Carnegie Mellon University, https://www.sei.cmu.edu/reports/09tr003.pdf (accessed: 1.09.2016).

Eisenhardt K.M., Martin J.A. (2000), Dynamic Capabilities: What Are They, "Strategic Management Journal", vol. 21, no 10-11, https://doi.org/10.1002/1097-0266(200010/ 11)21:10/11<1105::aid-smj133>3.0.co;2-e.

Flamholtz E.G., Randle Y. (2007), Successful Organizational Development and Growing Pains, Management Online Review, http://wfgcoyo.mgtsystems.com/sites/default/ files/Successful\%20Organizational\%20Development $\% 20$ and $\% 20$ Growing $\% 20$ Pains. pdf (accessed: 1.09.2016).

Galbreath J. (2005), Which Resources Matter the Most to Firm Success? An Exploratory Study of Resource-based Theory, "Technovation", vol. 25, no 9, https://doi. org/10.1016/j.technovation.2004.02.008.

Grant R.M. (1996), Toward a Knowledge-based Theory of the Firm, "Strategic Management Journal", vol. 17, no S2, https://doi.org/10.1002/smj.4250171110.

Greiner L.E. (1998), Evolution and Revolution as Organizations Growth, "Harvard Business Review", May-June.

Hammer M. (2007), The Process Audit, "Harvard Business Review", April.

Hanks S., Watson C., Jansen E., Chandler G. (1993), Tightening the Life-cycle Construct: A Taxonomic Study of Growth Stage Configurations in High-technology Organisations, "Entrepreneurship Theory and Practice", vol. 18, no 2.

Hatch N.W., Dyer J.H. (2004), Human Capital and Learning as a Source of Sustainable Competitive Advantage, "Strategic Management Journal”, vol. 25, no 12, https://doi. org/10.1002/smj.421.

Johanson J., Vahlne J-E. (1990), The Mechanism of Internationalization, "International Marketing Review", vol. 7, no 4.

Kirkpatrick D.L. (2007), Implementing the Four Levels: A Practical Guide for Effective Evaluation of Training Programs, Berrett-Koehler Publishers, San Francisco.

Kwon K., Rupp D.E. (2013), High-performer Turnover and Firm Performance: The Moderating Role of Human Capital Investment and Firm Reputation, "Journal of Organizational Behaviour", vol. 34, no 1, https://doi.org/10.1002/job.1804.

Lepak D.P., Snell S.A. (1999), The Human Resource Architecture: Toward a Theory of Human Capital Allocation and Development, "The Academy of Management Review", vol. 24, no 1, https://doi.org/10.2307/259035.

Liu W. (2004), The Cross-national Transfer of HRM Practices in MNCs: An Integrative Research Model, "International Journal of Manpower", vol. 25, no 6, https://doi. org/10.1108/01437720410560415. 
Moumita N., Zaman L. (2013), An Analysis of Global Training and Experience Sharing in Multinational, "American Journal of Business and Management", vol. 2, no 1, https:// doi.org/10.11634/216796061302297.

Nikandrou I., Apospori E., Papalexandris N. (2008), Organisational Training and Development in the European Context: A Longitudinal Comparative Study among 18 European Countries, "European Journal of International Management", vol. 2, no 3, https://doi.org/10.1504/ejim.2008.019699.

Pauli U. (2015), Rozwój pracowników (in:) Zarządzanie zasobami ludzkimi na rynkach międzynarodowych, ed. A. Pocztowski, Oficyna a Wolter Kluwer Business, Warszawa.

Pike S., Roos G., Marr B. (2005), Strategic Management of Intangible Assets and Value Drivers in R\&D Organisations, "R\&D Management", vol. 35, no 2, https://doi.org/ 10.1111/j.1467-9310.2005.00377.x.

Pittiglio R., Sica E., Villa S. (2013), Innovation and Internationalization: The Case of Italy, "The Journal of Technology Transfer", vol. 34, no 6, https://doi.org/10.1007/ s10961-009-9107-5.

Pocztowski A. (2003), Kapitał intelektualny a zarzadzanie zasobami ludzkimi, „Zeszyty Naukowe Akademii Ekonomicznej w Krakowie", no 629.

Pocztowski A. (2007), Zarzadzanie zasobami ludzkimi, PWE, Warszawa.

Quinn R.E., Cameron K. (1983), Organizational Life Cycles and Shifting Criteria of Effectiveness: Some Preliminary Evidence, "Management Science", vol. 29, no 1, https://doi.org/10.1287/mnsc.29.1.33.

Schultz T.W. (1961), Investment in Human Capital, "The American Economic Review", vol. 51, no 1.

Scott M., Bruce R. (1987), Five Stages of Growth in Small Business, "Long Range Planning", vol. 20, no 3, https://doi.org/10.1016/0024-6301(87)90071-9.

Shaw J.D., Park T-Y., Kim E. (2013), A Resource-based Perspective on Human Capital Losses, HRM Investments, and Organizational Performance, "Strategic Management Journal", vol. 34, no 5, https://doi.org/10.1002/smj.2025.

Simon H.A. (1991), Bounded Rationality and Organizational Learning, "Organization Science", vol. 2, no 1, https://doi.org/10.1287/orsc.2.1.125.

Szulanski G. (1996), Exploring Internal Stickiness: Impediments to the Transfer of Best Practice within the Firm, "Strategic Management Journal", vol. 17, no S2, https://doi. org/10.1002/smj.4250171105.

Valle R., Martin F., Romero P.M., Dolan S.L. (2000), Business Strategy, Work Process and Human Resource Training: Are They Congruent?, "Journal of Organizational Behaviour", vol. 21, no 3, https://doi.org/10.1002/(sici)1099-1379(200005)21:3<283::aid-job16>3.0.co;2-c.

\section{Organizacja procesu szkoleniowego w polskich firmach dzialających na rynkach międzynarodowych}

(Streszczenie)

Szkolenia są procesem umożliwiającym pracownikom rozwój zarówno ogólnych, jak i specyficznych dla każdej firmy kompetencji. W przedsiębiorstwach działających na rynkach międzynarodowych takie szkolenia zapewniają także transfer najlepszych praktyk, procedur i standardów działania z firmy macierzystej do filii. Osiąganie celów 
szkoleniowych wymaga więc, by proces doskonalenia kompetencji pracowników był zaprojektowany i realizowany w sposób profesjonalny, co dla firm działających na homogenicznych rynkach nie stanowi zbyt dużego wyzwania. Internacjonalizacja powoduje jednak, że organizowanie procesów personalnych wymaga uwzględnienia dodatkowych czynników związanych z różnorodnością, co może ograniczyć efektywność realizowanych dotychczas inicjatyw. W artykule wskazano na znaczenie procesu szkoleniowego w doskonaleniu kompetencji pracowników firm działających na rynkach międzynarodowych oraz zaprezentowano wyniki badań przeprowadzonych na grupie 50 polskich przedsiębiorstw działających na rynkach międzynarodowych. Celem tych badań była ocena stopnia profesjonalizacji działalności szkoleniowej oraz porównanie stosowanych praktyk do wytycznych ujętych w People Capability Maturity Model.

Słowa kluczowe: szkolenia, przedsiębiorstwa międzynarodowe, kapitał ludzki, zdolności organizacyjne, rozwój organizacji. 